\title{
WORLD AND NATIONAL PRINCIPLES OF ORGANIZATION, FUNCTIONING AND FINANCING OF CIVIL SOCIETY ORGANIZATIONS
}

\begin{abstract}
The article discusses and generalizes the principles of creation, operation and financing of civil society organizations that are used and understood in international practice. Specialized legal acts regulating the activity of nongovernmental organizations in Ukraine have been analyzed to determine the principles of activity and financing of non-governmental organizations.Also, their compliance with the principles approved by the world-wide authoritative civil society organizations was investigated. It is revealed that not all national regulative acts contain the following principles. This situation creates significant difficulties for the activities of certain types of non-governmental organizations in Ukraine (including the formation and using of financial resources) and complicates the process of state control over civil society institutions. Thus, it is suggested to use a systematic approach, which should amend the regulations governing the activities of non-governmental organizations in Ukraine in order to remedy these shortcomings.
\end{abstract}

C Iryna Tkachuk, 2019.

Tkachuk Iryna, PhD, Associate Professor, Yuriy Fedkovych Chernivtsi National University, Ukraine. https://orcid.org/0000-0003-1081-8693. 


\section{Key words:}

Civil society, civil society institutions, non-governmental organizations, finance, law, financial security, financial resources.

JEL: G38, H41, L31, L38.

\section{Introduction}

The study of any phenomenon involves a deep critical analysis of the basics of its functioning. After all, the idea of an environment in which it affected, and at the same time exposed to its impact, is the basis for understanding the course of all processes associated with it. This is especially true of civil society finances, since the institutions of the CS are organizationally defined and operate under specific legal conditions that affect the formation, distribution, redistribution and using of their financial resources. That is why, when examining the finances of civil society, it is important to analyze critically the organizational and legal foundations of its functioning.

\section{Analysis of recent publications}

The problems of creation and functioning of civil society institutions, as well as some aspects of the finances of non-governmental organizations, are devoted to the work of foreign and domestic scientists, in particular: D. Barlet, N. Bulein, A. Croissant, M. Edwards, G. Louth, V. Merkel, T. Pafengoltz, T. Pryve, J. Shade, Spark, R. Toftisova et al. There was the interest for the CS organizations among the national scientists too. Azarov, V. Bakalchuk, L. Vasylenko, S. Zelinsky, O. Vinnikov, D. Gorelov, N. Dehtyar, S. Doroshenko, O. Kirylenko, Kodatsky, T. Malyovanaya, O. Marchenko, A. Matviychuk, V. Pashchenko, O. Piltiai, G. Piratovsky, O. Poznyak, O. Rozhko, P. Sytnik, L. Usachenko, A. Fomenko, N. Shvets, etc are the aythors of the most important works. 

and financing of civil society organizations

In paying tribute to the scientific work of the aforementioned scientists, it is worth noting that the study of the principles of the activities of non-governmental organizations and their reflection in the national legislation remains relevant.

Therefore, the aim of the article is to examine national legislation for the principles of organizing, functioning and funding of civil society institutions and their consistency with good international practice.

\section{Result of investigation}

\section{World principles of non-governmental organizations}

The basis for organizing the activities of civil society institutes (hereinafter CSOs) are the principles of their activity, which are determined by logic, based on their essence, and are enshrined in regulatory legal acts. That is why we will explore the best world practice of forming principles of CSO activity and compare them with the Ukrainian one.

In world best practice, a number of organizations can be identified that determine the principles of formation and activity of CSOs. These include the Caux Round Table for Moral Capitalism; Bureau of Democracy, Human Rights and Labor of the United States; OSCE, as well as various non governmental organizations' platforms (hereinafter referred to as NGOs). It is important to consider their approaches to highlight the principles of formation and activity of CSOs.

The Round Table on Moral Capitalism (hereinafter referred to as the Roundtable), established in 1986 by leading businessmen in Europe, Japan and the US, affirms its primary purpose of enhancing the role of business and industry as a driving force for progressive global change (Caux round Table. Principles For non-governmental organizations). The Round Table elaborated the principles of formation and activity of CSOs, which are divided into fundamental and secondary (Caux round Table. Principles For non-governmental organizations).

There is only one fundamental principle of CSOs. It is the integrity of activities, according to which a non-governmental organization recognizes that it is a quasi-governmental structure that is endowed with certain resources and reputation, which it must use for achieving its own goals, adapted to the common good 
(in better way). All actions of an NGO must be in line with its primary objectives. Its management and staff may not use their position (within the organization) for any personal advantage, and especially for personal financial gain. Loyalty to them and their due care in fulfilling their mission are the hallmarks of responsible NGOs (Caux round Table. Principles For non-governmental organizations).

Other principles of activity of NGOs, which Roundtable defines, are public benefit, transparency, participatory governance, independence, and respect for the law, care and accountability (Caux round Table. Principles For nongovernmental organizations).

- Public benefit means that all actions and efforts of NGOs reflect the interests of the people who fund, organize, promote, or support in other way the organization as well as the social, cultural, political, economic and environmental interests of such people.

- Transparency in the activities of CSOs is determined by the fact that it influences other aspects of society wxisting in order to achieve its goals. That is why they should be transparent about their own goals; values and principles; management; activities; resources spent to achieve the set goals.

Closeness is only allowed within the limits of protecting the legitimate privacy rights of the founders and members.

The principle of participatory governance means that CSOs are created as institutions whereby individuals (natural or legal) express their opinions, expend their efforts, and provide financial resources to achieve certain public benefits, thus NGOs' leadership must adhere to the highest trusting obligations in terms of transparency and responcibility, loyalty and due diligence in decision making process and fund management process.

The principle of independence implies disclosure of all legal, organizational and financial links with corporations, governments or other organizations that can significantly affect the intentions, actions and consequences of activities of a NGO.

Principle of respect for the law - in their activities CSOs show the highest respect for both international and national legislation. Ignoring legal obligations leads to legal liability.

Care as a principle of NGOs means that NGOs planning their actions or implementing their policies show concern for those whose interests they cross through their activities. If a NGO harms a government, international organization, corporation or other party, it will be held responsible for its actions.

Accountability means that non-governmental organizations periodically (at least once a year) publishes information containing a report on the organization itself, its activities, programs, fundraising and financial performance. 

and financing of civil society organizations

It is important to emphasize that all principles of the formation and operation of CSOs of Roundtable (both fundamental and secondary) contain provisions on the formation and use of CSOs financial resources, indicating that the international organization is aware of the importance of this component in their activities, and the gravity of the consequences of violation of these principles.

The US Bureau of Democracy, Human Rights and Labor, recognizing that NGOs are important to the existence and development of free societies and that they play an important role in providing accountable, democratic power. It outlines 10 basic principles for NGOs (Bureau of Democracy, Human Rights, and Labor, U. S. Department of State (2006). Guiding Principles on NonGovernmental Organizations.):

1. Individuals have the right to participate in the activities and formation of NGOs in the process of realizing of their rights for freedom of expression, peaceful assembly and association.

2. Any restrictions that may be placed on the exercise by members of an $\mathrm{NGO}$ of the right to freedom of expression, peaceful assembly and association are in conformity with international legal obligations.

3. Non-governmental organizations have the right to conduct their peaceful activities freely and without persecution.

4. Laws and administrative measures promote, but do not impede, the peaceful work of NGOs and are apolitical, fair, transparent and consistent.

5. Governmental actions against NGOs are based on the principles of due process and equality before the law.

6. Non-governmental organizations have the right to seek, obtain, direct and administer their peaceful activities with the financial support of national, foreign and international organizations.

7. NGOs have the freedom to seek, receive and impart information and ideas, in particular to express their views to governments and the public within and outside the countries on which they are based.

8. Governments do not interfere with the access of NGOs to the media at national and international levels.

9. NGOs are free to liaise with, and co-operate with their own members and other elements of civil society within and outside their host countries, as well as with governments and international bodies.

10. Whenever the principles of NGOs outlined above are violated, democratic nations act to protect them.

Consequently, the Bureau of Democracy, Human Rights and Labor pays less attention to building the financial relations of CSOs, focusing on the organ- 
izational and legal features of their activities. At the same time, these principles provide financial support to various donors of CSOs, both national and foreign. It is interesting to note that such a right of CSOs is obvious to developed and democratic states, while in states that are not democratic or democratic in declarative terms, this right is not obvious. For example, in Russia, the Law on Foreign Agents (Foreign agent. Wikipedia) has been in force since 2012, which limits the receipt of financial assistance from abroad for NGOs. An attempt was made to adopt a similar law in Ukraine in January 2014, however, this decision led to widespread opposition among the population and was repealed within 2 weeks after its adoption (Foreign agent. Wikipedia).

Another organization that thoroughly studies the problems of existence and promotes the development of the civil society is the OSCE. Accordingly, the OSCE outlines the basic principles of NGO activity, namely the voluntary nature of creation; the right to freedom of expression; Equality of rights and obligations with other legal entities; judicial protection (OSCE, 2004, Fundamental Principles on the Status of Non-governmental Organizations in Europe).

Volunteer creation. The starting point of any law on NGOs is the right of any individual or legal person to create NGOs for legitimate purposes, among which there is no profit. The establishment of a non-profit organization is a voluntary act. It is important that national legislation on NGOs, as well as the rules on their taxation, do not impede and encourage such initiatives in every way.

The right to freedom of expression of the European Convention on Human Rights (European Convention on Human Rights., Art. 10) applies to NGOs at the level of other individuals or legal entities.

Equality of rights and obligations with other legal entities. NGOs operate in accordance with customary legal rules in the territory of the country, they are not subject of specific rules, although separate laws may be adopted to provide NGOs with additional rights or to promote their activities.

Judicial protection. NGOs have the right to challenge decisions concerning them in an independent court. The NGOs legislation does not contain any specific provisions in this regard.

An important principle for the activities of NGOs allocated by the OSCE is the principle of equality of rights and obligations with other legal entities, since it signifies equality of rights and obligations in the formation of the financial resources needed to fulfill the statutory goals of their activity.

Another key document defining the principles of the NGOs of the world is the Joint Paper of NGO Platforms: Brazil, Canada, Chile, Europe, France, Spain and the USA, and the United States (Principles and Recommendations for International NGO Participation in Haiti Recovery, Reconstruction and Development. Joint Paper of NGO Platforms: Brazil, Canada, Chile, Europe, France, Spain, and the United States). This document provides guidelines for the activities of interna- 

and financing of civil society organizations

tional NGOs, prepared with the participation of NGO platforms around the world. For our study, it is important in the sense that the principles of the NGO's activities that it contains relate specifically to the sphere of finance of these organizations. Thus, the principles of NGOs activity include the principles of accountability; cooperation and coordination; a human rights-oriented approach; increasing local capacity.

The principle of accountability means involving the state and municipal authorities, and, most importantly, local communities, in the formulation of programs to address the key issues affecting them, by regularly reporting on their actions, on the involved financial resources and the directions of their use, etc. (Principles and Recommendations for International NGO Participation in Haiti Recovery, Reconstruction and Development. Joint Paper of NGO Platforms: Brazil, Canada, Chile, Europe, France, Spain, and the United States).

The principle of cooperation and coordination shows the need to move in one strategic direction for CSOs, State and business. In the public service delivery process, these three sectors should help one another achieve the goal, including through the use of resources from diverse sources (Principles and Recommendations for International NGO Participation in Haiti Recovery, Reconstruction and Development. Joint Paper of NGO Platforms: Brazil, Canada, Chile, Europe, France, Spain, and the United States).

The principle of using a human rights approach. NGOs are committed to protecting human rights, including their social, economic, cultural, civil and political rights (Principles and Recommendations for International NGO Participation in Haiti Recovery, Reconstruction and Development. Joint Paper of NGO Platforms: Brazil, Canada, Chile, Europe, France, Spain, and the United States).

The principle of increasing local capacity. Since local communities are independently responsible for their own regeneration and development, the activities of NGOs are aimed at increasing the capacity of local communities to address their own social and economic needs. fig. 1.

The above mentioned principles of NGOs activity are grouped as shown in

The visual depiction of the NGOs principles as in (Fig. 1) makes it possible to highlight the principles that are most important for NGOs, as they are common to all the organizations studied. Such principles are the principles of voluntary creation; focus on public benefit; cooperation with other entities to achieve the goal of the activity; accountability; equality of rights and freedoms; legal protection of activity. 
Fig. 1

Principles of creation and activity of NGOs of leading international organizations*
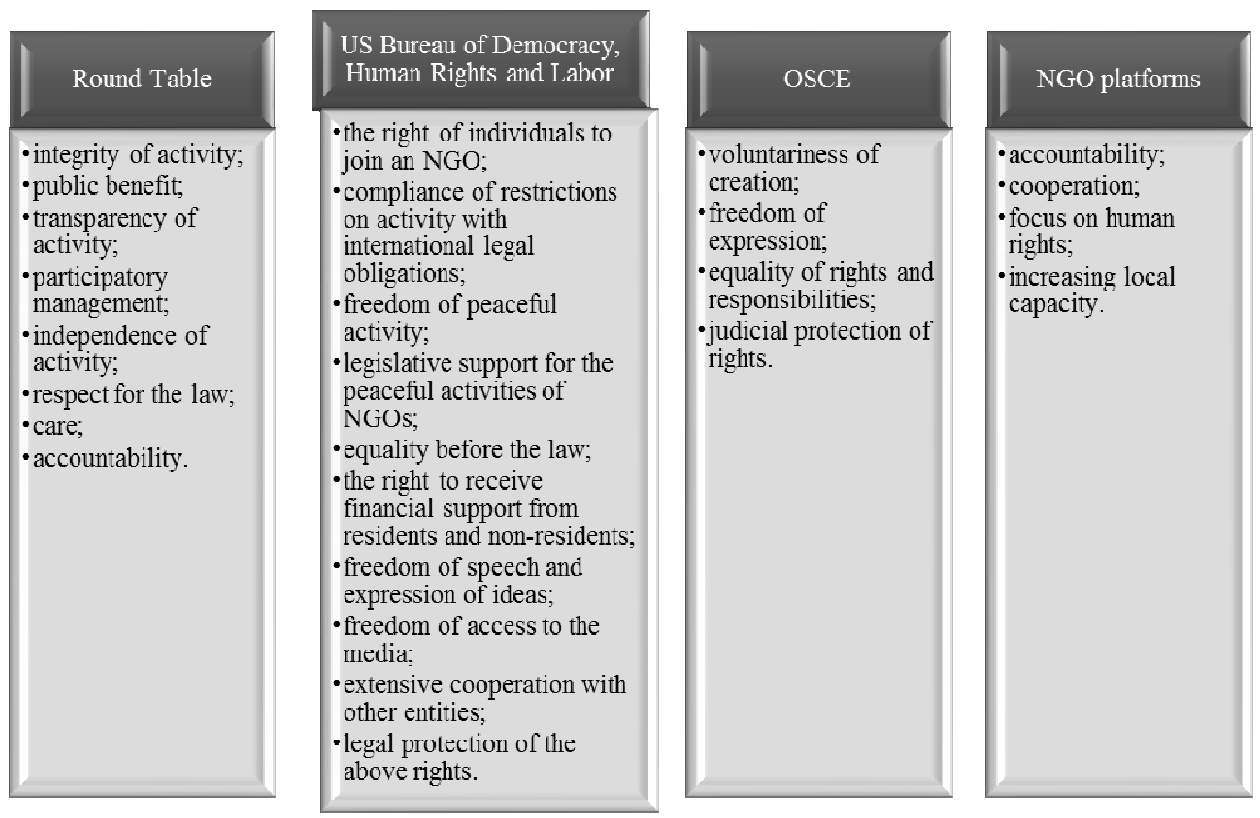

* Generalized by author based on $(1,3,4,5)$

\section{National principles of non-governmental organizations}

Despite the fact that the civil society in Ukraine is in its infancy and the sphere of finances of it is only at the stage of creation, the domestic legislation governing the existence of it and the activities of its institutions clearly defines the basic principles of NGOs activity in Ukraine, reflecting the best world practice.

Thus, Law of Ukraine «On Public Associations» outlines six basic principles of formation and activity of public associations in Ukraine, namely voluntariness; self-government; free choice of territory of activity; equality before the law; lack of property interest of their members (participants); transparency, openness and publicity (Law of Ukraine on public associations № 4572-VI, 2018, July 22, p. 3). The basic principles of creation and activity of public associations in Ukraine are presented in fig. 2. 
Fig. 2

The principles of creation and activity of public associations in Ukraine (Law of Ukraine on public associations № 4572-VI, 2018, July 22, art. 3)

Voluntariness
-the right of a person to participate freely in a public association (its
formation, entry into such association or termination of membership
(participation) in it)

Since the Law of Ukraine "On Public Association» is the basis for the activities of CSOs in Ukraine, it creates general rules for their activities. Nevertheless, Art. 2 states that its activities do not extend to public relations in the sphere of formation, registration, activity and termination of political parties; religious organizations; non-business societies formed by acts of state authorities, other state bodies, local self-government bodies; associations of local self-government bodies and their voluntary associations; self-regulatory organizations, professional self-government organizations; non-business societies (which are not public associations) formed on the basis of Law of Ukraine on public associations № 4572-VI, 2018, July 22). (Law of Ukraine on public associations № 4572-VI, 2018, July 22, art. 2). That is why it is important to consider special legislation that regulates the activities of other CSOs.

It should be noted that the main legal acts are Law of Ukraine «On professional unions, their rights and guarantees of activity» (Law of Ukraine On Trade 
Unions, Their Rights and Guarantees of Activities № 1045-XIV, 2018, November), Law of Ukraine «On professional creative workers and creative unions» (Law of Ukraine on Professional Creative Workers and Creative Unions № 554/97-BP, 2018, November 4), Law of Ukraine «On employers' organizations, their associations, rights and guarantees of their activity» (Law of Ukraine On Employers' Organizations, Their Associations, Rights and Guarantees of Their Activities № 5026-VI, 2016, November 2), Law of Ukraine «On bodies of self-organization of the population» (Law of Ukraine On the bodies of selforganization of the population № 2625-III, 2018, November 4), Law of Ukraine «On charitable activity and charitable organizations» (Law of Ukraine on charitable activities and charitable organizations № 5073-VI, 2016, October 6), Law of Ukraine «On freedom of conscience and religious organizations» (Law of Ukraine on Freedom of Conscience and Religious Organizations № 987-XII. (2019, January 31), Law of Ukraine «On political parties in Ukraine» (Law of Ukraine on Political Parties in Ukraine № 2365-III. (2018, October 1). The results of generalizing the principles of organization, formation and activity of non-governmental organizations of Ukraine are presented in Fig. 3.

Such Laws as «On trade unions, their rights and guarantees of activity», «On professional creative workers and creative unions», "On organizations of employers, their associations, rights and guarantees of their activity», "On bodies of self-organization of the population» contain those the principles of formation and activity of civil society organizations to which they refer. However, Law of Ukraine «On Charity and Charitable Organizations», Law of Ukraine «On Freedom of Conscience and Religious Organizations», Law of Ukraine «On Political Parties in Ukraine» do not contain provisions regarding the principles of activity of the respective organizations. As for the non-state media, there is no specific legislation at all in Ukraine regulating their activity.

\section{Conclusions}

A study of the principles of NGOs of the world's leading organizations has shown that the basic approaches to the organization, operation and financing of non-governmental organizations are recognized in the world. Thus, common principles, that every organization, which tries to create rules for NGOs, recognizes, are principle of voluntary creation; focus on public benefit; cooperation with other entities to achieve the goal of the activity; accountability; equality of rights and freedoms; legal protection of activity. 
Fig. 3

Principles of formation and activity of NGOs in Ukraine, which are distinguished by special legislation*

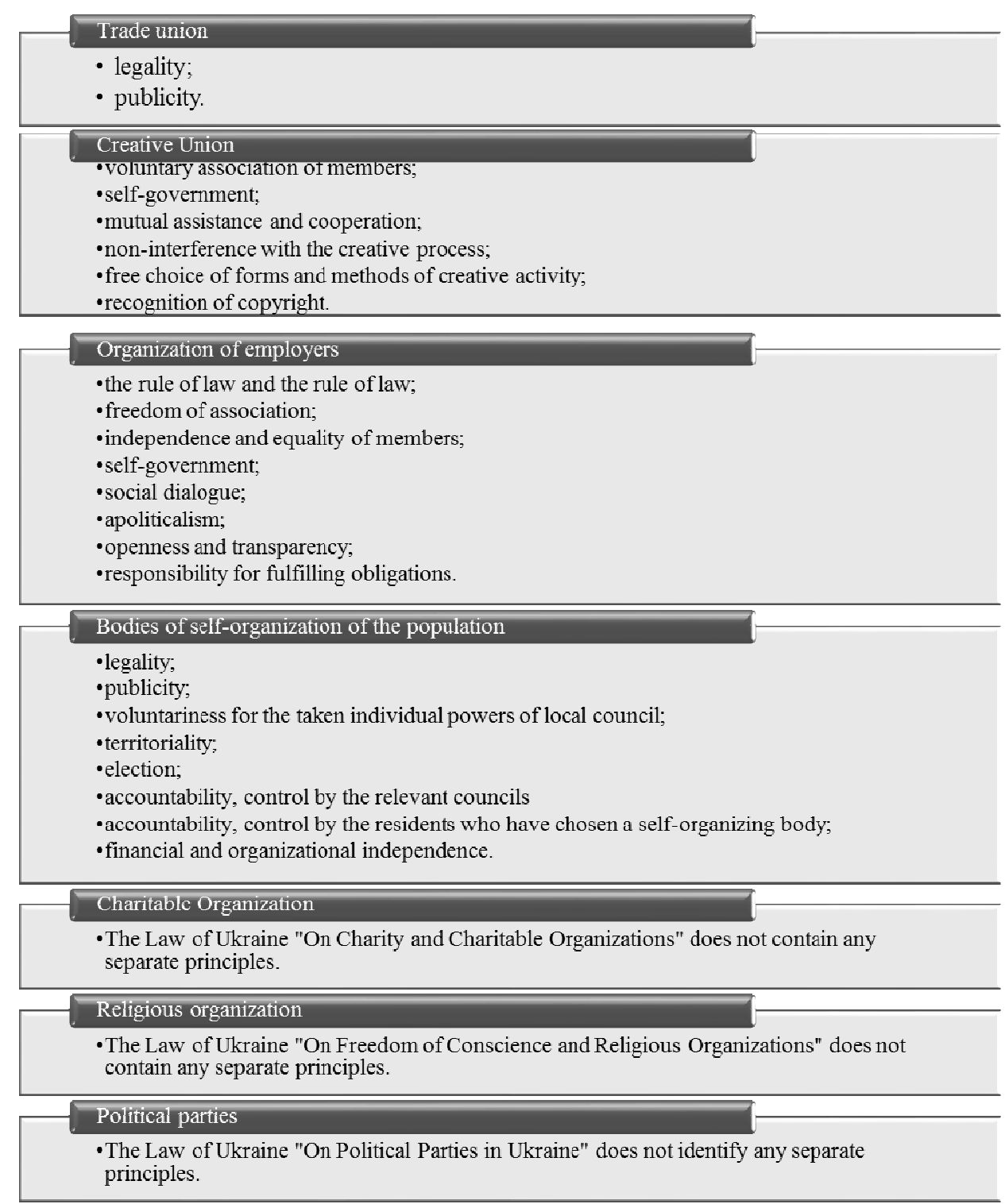

* Generalized by $(9,10,11,12,13,14,15,16)$. 
In Ukrainian legal practice, there are at the same time a considerable number of specialized legal acts regulating the formation and activities of various types of non-governmental organizations. The main such legal acts are: Law of Ukraine «On charitable activities and charitable organizations»; Law of Ukraine "On public associations"; Law of Ukraine "On the bodies of self-organization of the population»; Law of Ukraine "On Employers' Organizations, their associations, rights and guarantees of their activities»; Law of Ukraine «On political parties in Ukraine»; Law of Ukraine "On professional creative workers and creative unions»; Law of Ukraine "On trade unions, their rights and guarantees of activities»; Law of Ukraine "On freedom of conscience and religious organizations».

It is important that along with the fact that some of the mentioned laws contain a practically exhaustive list of principles of creation, operation and financing of NGOs, which are recommended by world practice, such laws of Ukraine as "On charitable activity and charitable organizations", "On freedom of conscience and religious organizations», "On political parties in Ukraine «do not pay attention to them at all.

Such situation does not stimulate civil society organizations for activity in Ukraine and does not promote the development of its civil society. The lack of clear rules for the formation and functioning of certain types of civil society organizations significantly complicates their activities and forces them to register themselves in the form of other organizations, which at the same time makes it impossible for the state to control the activity of such organizations. That is why, the current legislation requires a significant improvement in the rules governing the formation and activities of NGOs. This process, of course, must be carried out by a systematic approach. Therefor, the amendments should not relate to the provisions of individual legislative acts, but should be introduced in such a way that all legislative acts are fully consistent with each other.

\section{References}

1. Bureau of Democracy, Human Rights, and Labor, U. S. Department of State (2006). Guiding Principles on Non-Governmental Organizations. URL: https://2001-2009.state.gov/g/drl/rls/77771.htm

2. Caux Round Table for Moral Capitalism. URL: http://www.cauxroundtable.org/ index.cfm?\&menuid=28\&parentid $=2$

3. Caux round Table. Principles For non-governmental organizations. URL: http://docplayer.net/25467969-Principles-for-non-governmentalorganizations.html

4. OSCE (2004), Fundamental Principles on the Status of Non-governmental Organizations in Europe. URL: https://www.osce.org/ru/odihr/37859 

and financing of civil society organizations

5. Principles and Recommendations for International NGO Participation in Haiti Recovery, Reconstruction and Development. Joint Paper of NGO Platforms: Brazil, Canada, Chile, Europe, France, Spain, and the United States. URL: https://reliefweb.int/sites/reliefweb.int/files/resources/64BCF3129AAE7BEF4 92576F8000831A0-Full_Report.pdf

6. The Verkhovna Rada repealed «dictatorial laws» of January 16 (list). URL: https://detector.media/community/article/89852/2014-01-28-verkhovna-radaskasuvala-diktatorski-zakoni-vid-16-sichnya-perelik/ [in Ukrainian]

7. European Convention on Human Rights. URL: https://www.echr.coe.int/ Documents/Convention_UKR.pdf [in Ukrainian]

8. Foreign agent. Wikipedia. URL: https://ru.wikipedia.org/wiki/\%D0\%98\%D0\% BD\%D0\%BE\%D1\%81\%D1\%82\%D1\%80\%D0\%B0\%D0\%BD\%D0\%BD\%D1 \%8B\%D0\%B9_\%D0\%B0\%D0\%B3\%D0\%B5\%D0\%BD\%D1\%82 [in Russian]

9. Law of Ukraine on charitable activities and charitable organizations № 5073VI. (2016, October 6). URL: https://zakon.rada.gov.ua/laws/show/5073-17 [in Ukrainian]

10. Law of Ukraine on public associations № 4572-VI. (2018, July 22). Retrieved from https://zakon.rada.gov.ua/laws/show/4572-17 [in Ukrainian]

11. Law of Ukraine On the bodies of self-organization of the population № 2625III. (2018, November 4). Retrieved from https://zakon.rada.gov.ua/laws/ show/2625-14 [in Ukrainian].

12. Law of Ukraine On Employers' Organizations, Their Associations, Rights and Guarantees of Their Activities № 5026-VI. (2016, November 2). Retrieved from https://zakon.rada.gov.ua/laws/show/5026-17 [in Ukrainian].

13. Law of Ukraine on Political Parties in Ukraine № 2365-III. (2018, October 1). URL: https://zakon.rada.gov.ua/laws/show/2365-14 [in Ukrainian]

14. Law of Ukraine on Professional Creative Workers and Creative Unions №554/97-BP. (2018, November 4). Retrieved from https://zakon.rada.gov.ua/ laws/show/554/97-\%D0\%B2\%D1\%80 [in Ukrainian]

15. Law of Ukraine on Trade Unions, Their Rights and Guarantees of Activities № 1045-XIV. (2018, November 4). Retrieved from https://zakon.rada.gov.ua/ laws/show/1045-14 [in Ukrainian].

16. Law of Ukraine on Freedom of Conscience and Religious Organizations № 987-XII. (2019, January 31). Retrieved from https://zakon.rada.gov.ua/ laws/show/987-12 [in Ukrainian] 